\title{
Companhia colonial de navegação: a trajetória de uma empresa sob um regime imperial e autoritário
}

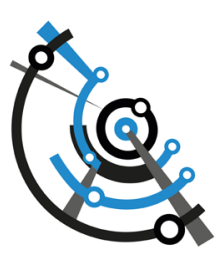

\section{Alcides Goularti Filho}

Programa de Pós-graduação em Desenvolvimento Socioeconômico, Universidade do Extremo Sul Catarinense, Brasil.

https://orcid.org/oooo-0002-0808-4486

\section{António Rafael Amaro}

Faculdade de Economia, Universidade de Coimbra, Portugal. https://orcid.org/oooo-0002-3843-6577

\author{
Álvaro Garrido \\ Faculdade de Economia, Universidade de Coimbra, Portugal. \\ https://orcid.org/oooo-0001-5424-8923
}

Recibido: 3 de octubre de 2019. Aceptado: 9 de diciembre de 2019.

\begin{abstract}
Resumo
O objetivo deste artigo é analisar a trajetória da Companhia Colonial de Navegação (CCN), uma empresa de navegação portuguesa fundada em 1922 e extinta em 1974, quando foi adquirida pela Companhia Portuguesa de Transportes Marítimos (CPTM). O artigo está dividido em cinco tópicos: 1) uma breve introdução sobre as prisões do tempo, do espaço e das liberdades individuais na trajetória de empresas; 2 ) uma sistematização do debate em torno do "problema" da marinha mercante portuguesa publicado em manifestos de especialistas do setor naval entre 1903 e 1939; 3) a formação do opressor complexo agrário-mercantil colonial, cujo participação da CCN era fundamental na estruturação da rede de transportes; 4) a trajetória da CCN apresentando os seguintes dados: evolução e renovação da frota, abertura de linhas, movimento comercial, resultados financeiros e composição do capital social; 5) por fim, a troca de favores entre a $\mathrm{CCN}$ e o estado corporativista que lhe garantia acesso a benefícios financeiros.
\end{abstract}

Palavras-chave: Navegação. Colonialismo. Empresa. Transporte. Economia. 


\begin{abstract}
The purpose of this article is to analyze the history of the Companhia Colonial de Navegação (CCN), a portuguese shipping company founded in 1922 and extinguished in 1974, when it was acquired by Companhia Portuguesa de Transportes Marítimos (CPTM). The article is divided into five topics: 1) a brief introduction on the prisons of time, space and individual freedoms in the trajectory of companies; 2) a systematization of the debate on the "problem" of the Portuguese merchant navy published in manifestoes of specialists of the naval sector between 1903 and 1939; 3) the formation of the colonial agrarian-mercantile complex oppressor, whose participation of the CCN was fundamental in the structuring of the transport network; 4) the CCN trajectory presenting the following data: evolution and renewal of the fleet, opening of lines, commercial movement, financial results and composition of the capital stock; 5) Finally, the exchange of favors between the $\mathrm{CCN}$ and the corporatist state that guaranteed access to financial benefits.
\end{abstract}

Keywords: Navigation. Colonialism. Company. Transport. Economy. Palabras clave: Navegación. Colonialismo Empresa Transporte Economía.

\title{
Introdução: o tempo, o espaço e os indivíduos
}

Fundada em 1922, a Companhia Colonial de Navegação passou por diversos momentos ímpares na história de Portugal até o dia 4 de fevereiro de 1974, quando foi fundida com a Empresa Insulana de Navegação (EIN), formando a Companhia Portuguesa de Transportes Marítimos (CPTM). Mudanças nos rumos da política e na economia interferiam diretamente na vida da companhia, que estava permanentemente ligada ao Estado português na espera de apoios financeiros ou de favores políticos.

Neste longo período, a sociedade portuguesa viu seu país sair de República demoliberal recém-fundada em 1910, para um Estado autoritário. Antes da fundação da CCN, Portugal havia participado ativamente da Primeira Guerra Mundial com aproximadamente 75.000 envolvidos. O pós-guerra inaugurou um período de instabilidade política e institucional que desmoralizava o regime político fundado nos partidos. $\mathrm{O}$ golpe de 28 de maio de 1926 instaurou uma ditadura militar que abriu espaço para o nascente fascismo e forjou os alicerces do Estado Novo. O novo regime, de caráter autoritário, colonialista e centralizador, perdurou por 41 anos, resistindo a insurgências e ofuscando as oposições. Sob a batuta de António de Oliveira Salazar (1933-1968) e Marcelo Caetano (1968-1974), a economia e a sociedade portuguesa viveram a síntese da modernização conservadora, em que surtos de industrialização e modernização das estruturas logísticas conviviam com o empobrecido modelo rural português.

No que concerne à marinha mercante, a República herdou o Ato de Navegação de 1863 e reforçou seu caráter nacional, que perdurou durante todo o Estado Novo. Em 1921, por meio do Decreto 7.822, de 22 de novembro, foi criado o Fundo de Proteção à Marinha Mercante e aos Portos Nacionais e, sob a Ditadura, com Salazar no Ministério das Finanças, foi aprovado o Decreto 20.321, de 18 de setembro de 1931, que estabeleceu os subsídios à navegação. Sob os auspícios do Estado corporativo, que tinha por objetivo politizar as diversas esferas da existência, em 1939, por meio do Decreto-Lei 29.962, de 09 de outubro, no limiar da Segunda Guerra, foi criada a Junta Nacional da Marinha Mercante (JNMM), cujas principais atribuições eram: coordenar, fiscalizar, fomentar, centralizar e promover ações de política voltadas ao setor naval como um todo. Por fim, para fomentar a renovação da frota nacional, o Decreto-Lei 35.876, de 24 de setembro de 1946, instituiu o Fundo de Renovação da Marinha Mercante 
(FRMM), que deveria conceder empréstimos aos armadores inscritos na JNMM que apresentassem proposta de renovação de sua frota.

No ambiente externo, a CCN enfrentou cenários adversos à renovação da frota e favoráveis à expansão das linhas. Nos anos 1930 e 1940, aproveitou o "isolamento" da economia portuguesa para renovar sua frota e sobreviveu à Segunda Guerra. Nas décadas seguintes, ao mesmo tempo em que se beneficiou do colonialismo, foi vítima dele com o início da Guerra Colonial em 1961. Além disso, a partir dos anos 1960, Portugal se aproximou mais das economias europeias por meio da assinatura de tratados multilaterais com repercussão direta em sua marinha mercante.

Em síntese, são 52 anos de uma companhia que navegou em mares ora com turbulência ora com calmaria. Uma empresa que entrecruzava decisões gerenciais internas com o ambiente externo em um país com transformações lentas. O objetivo deste artigo é descrever e analisar a trajetória da Companhia Colonial de Navegação a partir das soluções propostas por especialistas do setor naval português em "manifestos" publicados entre 1903 e 1939, destacando a renovação da frota, a abertura de linhas, o movimento comercial, os resultados financeiros e as mudanças na composição do capital. Dentro dos arranjos políticos e institucionais do Estado Novo, ao final apresentaremos algumas "troca de favores" entre a CCN e os agentes públicos. As principais fontes utilizadas foram os "manifestos" sobre o "problema da marinha mercante nacional", publicados entre 1900 e 1939; os relatórios da CCN, em uma série completa de 1935 a 1972 - sendo que no ano de 1936 foi publicada uma síntese dos anos de 1931 a 1935 -; o Diário do Governo (Decretos e Estatutos), além de outras fontes sobre temas específicos que serão apresentados ao longo do texto. Nossa hipótese é de que a CCN era uma empresa ancorada em dois pilares: o estado autoritário (salazarismo) e no colonialismo. A quebra desses dois regimes levou a bancarrota da Companhia Colonial de Navegação, cujo um dos pilares que a sustentava estava expresso no nome da empresa "Colonial". Como metodologia, adotamos a abordagem qualitativa, descritiva e análise documental. Destacamos como inédito a utilização das informações disponíveis na extensa coleção dos Relatórios e Contas da Companhias Colonial de Navegação entre os anos de 1936 e 1972, disponíveis na Biblioteca Nacional de Lisboa. A utilização dessa fonte nos permitiu elaborar séries temporais de média duração.

\section{Complexo colonial e fundação da CCN}

O "glorioso" passado marítimo português não foi reposto nos séculos XVIII e XIX. A abertura dos portos brasileiros, em 1808, seguido da independência, em 1822, foram duros golpes à marinha mercante lusitana, que perdia um amplo e cativo mercado. Somente na segunda metade do século XIX, na Era Fontista, é que a marinha de comércio começou a se reorganizar, com a fundação das primeiras companhias de navegação a vapor. Destacamos a criação da União Mercantil, em 1858, que iniciou com uma frota de seis navios e sobreviveu por 10 anos. Em 1868, foi fundada a Empresa Lusitana, que comprou a frota da União Mercantil. Em 1881, a Empresa Lusitana foi convertida na Empresa Nacional de Navegação (ENN), que seguiu ampliando seus ativos com a aquisição de vapores maiores para o longo curso e se tornou o maior armador português, com uma frota de 50.943 toneladas, entre a qual havia seis navios acima de 4 mil toneladas, com destaque para o moderno Moçambique, com 6.535 toneladas (Mattos, 1900). Em 1918, a ENN foi transformada na Companhia Nacional de Navegação (CNN). Outra companhia com longevidade foi a Empresa Insulana de Navegação (EIN). Fundada em Ponta Delgada no ano 1871, possuía três embarcações e atuava na linha entre Açores, Madeira e Lisboa. A Companhia Nacional de Carregadores Açoriana (CNCA), outro armador de Ponta Delgada, criada em 1920, se especializou 
no transporte de frutas (especialmente abacaxi) entre outros portos da Europa e Estado Unidos. Por fim, a Sociedade Geral de Comércio, Indústria e Transportes, fundada em 1919, com o objetivo de atender as demandas da Companhia União Fabril (CUF), da qual era subsidiária e atuava em diversos mercados (Ministério da Marinha, 1966).

Os principais acontecimentos que antecederam a fundação da Companhia Colonial de Navegação, em 3 de junho de 1922, estão relacionados aos resultados da Primeira Guerra Mundial e à constituição da Transportes Marítimos do Estado (TME), uma empresa estatal formada a partir dos 72 navios alemães arrastados para os portos portugueses em 1916.

Portugal entrou na Primeira Guerra em setembro de 1914 com o objetivo de defender suas colônias africanas, sobretudo Angola e Moçambique, da invasão germânica a partir de suas colônias no Sudoeste Africano Alemão (fronteira com Angola) e da África Oriental Alemã (fronteira com Moçambique). No final do conflito, Portugal manteve suas colônias, mas a tensão nas fronteiras persistiu. Se nos primeiros anos da República ocorreu certo afastamento das colônias, as ameaças aos territórios além-mar pós-1915, acenderam a luz vermelha e obrigaram o governo português a pensar novas estratégias para manter a integridade de suas colônias.

Após o fim da guerra, e com a devolução dos navios que estavam sob a custódia dos ingleses, o Estado português formou uma empresa estatal de navegação, a TME, que iniciou suas operações com muitas dificuldades financeiras e teve que recorrer diversas vezes ao Tesouro para saldar débitos persistentes. Além dos problemas financeiros, as queixas quanto à eficiência dos serviços levaram o governo a abortar prematuramente a primeira experiência de uma empresa de navegação estatal portuguesa. Após denúncias de má gestão, em 1921, a TME foi dissolvida e sua frota foi vendida em ata pública. Dos 42 navios leiloados, a Sociedade Geral, a CNN e a recém fundada CCN arremataram sete cada uma e a CNCA arrematou três navios. O restante, 16 navios, foi vendido para pequenas companhias (Companhia Colonial de Navegação, 1927).

Também temos que entender a formação da Companhia Colonial de Navegação como parte integrante de um opressor complexo agrário-mercantil colonial na relação de Portugal com suas colônias africanas. Sobretudo após a Primeira Guerra, cresceu o interesse em explorar ainda mais Angola e Moçambique por meio da formação de um complexo agrário-mercantil. Este complexo, com forte caráter opressor, resultava da combinação de várias unidades que interagiam e se complementavam na busca pela valorização do valor. Explorar o máximo possível as potencialidades da colônia com objetivo de enriquecer as elites locais e metropolitanas era o que movia as ações do Estado e dos capitalistas portugueses.

Tomemos Angola como exemplo. Para explorar os produtos exportáveis, havia um banco que financiava a comercialização, o Banco Ultramarino de Angola; casas comerciais que intermediavam as importações e exportações, a Sociedade Agrícola de Cassequel e a Companhia do Amboim; uma empresa agrícola que plantava e beneficia os produtos tropicais exportáveis, a Companhia Angolana de Agricultura; instituições destinadas a manter juridicamente o status de colônia, o Ministério das Colônias e suas autarquias; por fim, serviços de transportes, como os portos de Luanda, Lobito e Amboim, os Caminhos de Ferro de Benguela e de Amboim e a Companhia Colonial de Navegação.

Portanto, neste complexo colonial há diversos estágios do processo de acumulação agrária-mercantil: financiamento, produção, comercialização e transportes. Uma cadeia de negócios amparada pelo Estado português, que assumia um caráter opressor. 
Foi neste ambiente propício de formação do complexo, entre 1919 e 1922, quando estava se alargando a marinha de comércio portuguesa, que foi fundada, por Bernardino Alves Correia, a CCN. Essa fundação se deu a partir da união de três firmas: a Sociedade Agrícola de Ganda, com sede em Luanda, que havia adquirido o cargueiro General Allenby, fabricado em 1895, com 3.138 t e rebatizado de Ganda; a Companhia do Amboim, com sede em Lisboa, que atuava nos ramos de comércio e agricultura em Angola; e a casa comercial Ed. Guedes Ltda, com sede em Bissau, que havia comprado o navio de passageiros La Plata, fabricado em 1898, com $4.032 \mathrm{t}$ e rebatizado de Guiné (Companhia Colonial de Navegação, 1936; 1947). Bernardino era o exemplo do grande empresário que articulava o complexo agrário-mercantil colonial em várias frentes. Nasceu no dia 5 de setembro de 1879, em Leiria, Portugal filho de José Alves Corrêa e de Emília Maria da Cruz Miranda e faleceu a 24 janeiro de 1957, em Benfica, Lisboa. Ainda jovem, foi para a Angola, onde se estabeleceu em Luanda em atividades comerciais. Em 1919 fundou a Companhia Fabril e Pastoril de Benguela Velha, que em 1920 converteu-se na Companhia Amboim, que atuava no cultivo e na comercialização de café e cacau na fazenda Boa Entrada. Em 1921, fundou a Caminho de Ferros do Amboim, uma ferrovia que ligava Gabela, a zona agrícola, com o porto de Amboim. Em 1922, para transportar o café, foi fundada a CCN. E em 1925, a Companhia Amboim foi transformada na Companhia Angolana de Agricultura (Cada) (Lopes, 2002).

Ferrovia, porto e navegação era a tríade do transporte que sustentava o fluxo mercantil do complexo. Portanto, a CCN era uma unidade de transporte que atuava dentro do opressor complexo agrário-mercantil colonial.

\section{Evolução e renovação da frota}

Além dos dois primeiros navios Ganda e Guiné, para formar sua frota, foram adquiridos nos anos de 1924 e 1925, nos leilões da TME, sete navios que foram utilizados nas carreiras para as colônias africanas entre Portugal, Guiné, São Tomé e Angola, com escalas em Cabo Verde. Os sete navios da TME tinham uma idade média de 26,8 anos - sendo que duas embarcações, o Bissau (1.823 t) e o Mendes Barata (3.869 t) tinham, respectivamente, 41 e 31 anos - e ao todo somavam 26.268 t. Para a época, era uma média de obsolescência não muito alta. Excluindo o Lobito (2.783 t) - o mais novo, com 18 anos, e o último a ser vendido deste lote de aquisições, em 1951 - o restante foi vendido do final da década de 1920 até meados da década seguinte, obedecendo a ordem de obsolescência.

Mesmo acumulando um capital de 15.000.000\$00, a companhia se viu na incapacidade de saldar seus débitos pelas aquisições da TME. Para tanto, o governo da Ditadura Militar, a exemplo dos benefícios cedidos à CNN em 1926, editou o Decreto 13.101, de 29 de fevereiro de 1927, que reconhecia as dificuldades financeiras da companhia e concedia um subsídio de $3.800 .000 \$ 00$ para saldar os débitos com a TME e cobrir os gastos com os reparos feitos nas embarcações, além de mais 12.000.000\$00 "para regularizar a sua situação financeira”. Totalizando $15.800 .000 \$ 00$, a dívida com o Tesouro deveria ser amortizada em 40 prestações semestrais com juros de 6,0\% ao ano (Portugal, 1926).

As vendas dos ex-alemães foram acompanhadas da aquisição de um lote de nove embarcações realizada entre 1928 e 1931, num total de 39.913 t. Novamente a média de idade foi alta - excluindo o navio Sena (1.221 t), que tinha sete anos, os demais giravam em torno de 24 anos. A maioria dessa frota foi repassada para frente no início dos anos 1950, quando a CCN iniciou um novo ciclo de modernização, sendo que o Pungue (4.018 t) resistiu por 31 anos e foi vendido em 1961 (Quadro 1). 
O Decreto 20.700 de 31 de dezembro de 1931, que disciplinou as atividades administrativas das companhias de navegação portuguesa também criou o Fundo de Aquisições de Navios, que deveria ser obrigatoriamente organizado por cada empresa. Os recursos seriam constituídos de títulos do Tesouro e do governo português, além de depósitos junto a Caixa Geral de Depósito. A CCN formou este Fundo em 1933, quando foram depositados $537.706 \$ 46$, tendo um crescimento significativo durante a primeira metade dos anos de 1940, chegando a 186.013.823\$81 em 1946, quando foi substituído pelo FRMM (Quadro 1). Esse aumento tem uma relação com o bom desempenho que teve a economia portuguesa no final dos anos de 1930 e início dos 1940, fundada no fascismo salazarista.

Quadro 1. Fundo de Renovação da Frota da CCN (1933-1946).Fonte: Relatórios e Contas da Companhia Colonial de Navegação, 1936-1947.

\begin{tabular}{|c|c|}
\hline Ano & Fundo de Aquisições de Navios (em Escudo) \\
\hline 1933 & $537.706 \$ 46$ \\
\hline 1934 & $963.000 \$ 35$ \\
\hline 1935 & $963.000 \$ 35$ \\
\hline 1937 & $1.190 .472 \$ 00$ \\
\hline 1938 & $3.449 .166 \$ 42$ \\
\hline 1939 & $3.784 .505 \$ 04$ \\
\hline 1940 & $3.951 .012 \$ 38$ \\
\hline 1941 & $26.454 .576 \$ 00$ \\
\hline 1942 & $42.108 .947 \$ 74$ \\
\hline 1943 & $70.643 .463 \$ 84$ \\
\hline 1944 & $113.973 .329 \$ 74$ \\
\hline 1945 & $159.953 .852 \$ 46$ \\
\hline 1946 & $186.013 .823 \$ 81$ \\
\hline
\end{tabular}

Com a utilização dos recursos do Fundo de Aquisições de Navios, a Colonial realizou, durante a Segunda Guerra Mundial, algumas compras. Foram mais seis navios, num total de 26.270 t e 25,6 anos de média de idade, incluindo o Serpa Pinto (8.077 t), um grande navio de passageiro, que se tornou uma referência para a CCN no transporte de refugiados de Lisboa para as Américas. Durante o período beligerante, foram abatidos por submarinos alemães dois navios da CCN: o Ganda 2 (4.333 t), em 20 de junho de 1941, com a morte de três indivíduos e um total de 72 naufragados; e o Cassequel (4.751 t), em 14 de dezembro de 1941, sem perdas de vidas e um total de 31 naufragados (Quadro 2). 
Quadro 2. Evolução e composição da frota da CCN (1922-1974). Fonte: Relatórios e Contas da Companhia Colonial de Navegação, 1936-1973.

\begin{tabular}{|c|c|c|c|c|c|c|}
\hline Navio & Construção & Aquisição & Venda & $\begin{array}{l}\text { Toneladas } \\
\text { (TAB) }\end{array}$ & $\begin{array}{l}\text { Idade na } \\
\text { compra }\end{array}$ & $\begin{array}{l}\text { Anos de } \\
\text { uso }\end{array}$ \\
\hline Ganda (1) & 1895 & 1922 & 1929 & 3.138 & 27 & 7 \\
\hline Guine (1) & 1898 & 1922 & 1930 & 4.032 & 24 & 8 \\
\hline Lobito (1) & 1906 & 1924 & 1953 & 2.783 & 18 & 29 \\
\hline Bissau & 1884 & 1925 & 1929 & 1.823 & 41 & 4 \\
\hline Amboim (1) & 1898 & 1925 & 1933 & 3.634 & 27 & 8 \\
\hline Benguela (1) & 1905 & 1925 & 1933 & 4.269 & 20 & 8 \\
\hline $\begin{array}{l}\text { Mendes } \\
\text { Barata }\end{array}$ & 1895 & 1926 & 1927 & 3.869 & 31 & 1 \\
\hline Luanda (1) & 1900 & 1926 & 1938 & 5.139 & 26 & 12 \\
\hline Cassequel & 1901 & 1926 & 1941 & 4.751 & 25 & 15 \\
\hline João Belo & 1905 & 1928 & 1950 & 6.475 & 23 & 22 \\
\hline Colonial & 1908 & 1929 & 1950 & 8.371 & 21 & 21 \\
\hline Sena (1) & 1922 & 1929 & 1952 & 1.221 & 7 & 23 \\
\hline Mouzinho & 1907 & 1929 & 1954 & 8.410 & 22 & 25 \\
\hline Malange (1) & 1905 & 1929 & 1956 & 3.155 & 24 & 27 \\
\hline Ganda (2) & 1907 & 1930 & 1941 & 4.333 & 23 & 11 \\
\hline Guine (2) & 1905 & 1930 & 1950 & 2.648 & 25 & 20 \\
\hline Pungue (1) & 1900 & 1930 & 1961 & 4.018 & 30 & 31 \\
\hline Buzi (1) & 1903 & 1931 & 1934 & 1.282 & 28 & 3 \\
\hline Serpa Pinto & 1915 & 1940 & 1955 & 8.077 & 25 & 15 \\
\hline Luango & 1905 & 1942 & 1949 & 4.298 & 37 & 7 \\
\hline Bailundo (1) & 1914 & 1943 & 1949 & 3.143 & 29 & 6 \\
\hline Huambo & 1919 & 1943 & 1950 & 4.141 & 24 & 7 \\
\hline Buzi (2) & 1921 & 1943 & 1951 & 1.387 & 22 & 8 \\
\hline Lugela (1) & 1926 & 1943 & 1971 & 5.224 & 17 & 28 \\
\hline Benguela (2) & 1946 & 1946 & 1974 & 5.094 & 0 & 28 \\
\hline Lunda & 1944 & 1947 & 1956 & 1.892 & 3 & 9 \\
\hline Pebane & 1944 & 1947 & 1956 & 1.953 & 3 & 9 \\
\hline Quionga & 1945 & 1947 & 1956 & 1.906 & 2 & 9 \\
\hline Patria & 1947 & 1947 & 1973 & 13.196 & 0 & 26 \\
\hline Ganda (3) & 1947 & 1947 & 1974 & 5.895 & o & 27 \\
\hline Luanda (2) & 1948 & 1948 & 1973 & 5.941 & o & 25 \\
\hline Amboim (2) & 1947 & 1948 & 1974 & 5.941 & 1 & 26 \\
\hline Imperio & 1947 & 1948 & 1974 & 13.186 & 1 & 26 \\
\hline Chaimite & 1950 & 1950 & 1973 & 2.043 & 0 & 23 \\
\hline Nampula & 1950 & 1950 & 1973 & 2.043 & o & 23 \\
\hline Sena (2) & 1952 & 1952 & 1973 & 1.700 & o & 21 \\
\hline Vera Cruz & 1952 & 1952 & 1973 & 21.765 & 0 & 21 \\
\hline Santa Maria & 1953 & 1953 & 1973 & 20.906 & 0 & 20 \\
\hline Uige & 1954 & 1954 & 1974 & 10.001 & 0 & 20 \\
\hline Lobito (2) & 1959 & 1959 & 1974 & 5.981 & o & 15 \\
\hline $\begin{array}{l}\text { Infante Dom } \\
\text { Henrique }\end{array}$ & 1961 & 1961 & 1974 & 23.306 & o & 13 \\
\hline Porto & 1968 & 1968 & 1974 & 9.220 & o & 6 \\
\hline Bailundo (2) & 1969 & 1969 & 1974 & 11.586 & o & 5 \\
\hline Malange (2) & 1971 & 1971 & 1974 & 12.203 & 0 & 3 \\
\hline $\begin{array}{l}\text { Bernardino } \\
\text { Correa }\end{array}$ & 1972 & 1972 & 1974 & 11.612 & 0 & 2 \\
\hline
\end{tabular}


A dificuldade em renovar a frota durante a guerra e a rápida obsolescência levou a marinha mercante portuguesa ao estrangulamento em 1945. Esta era uma realidade também para as demais companhias de navegação que adquiriam navios velhos e eram obrigadas a fazer constantes reparos de alto custo. Compensava vender a embarcação que estava com problemas e comprar outra usada em melhores condições. Fazer a manutenção constante demorava e implicava em perdas financeiras. Porém, essa estratégia estava chegando a seu limite, segundo o Relatório da CCN, de 1943.

Ou a frota mercante nacional é renovada e aumentada, ou o país, possuidor de vasto império ultramarino, voltará a depender, durante largos anos, das marinhas mercantes estrangeiras, à custa dos interesses da economia nacional (Companhia Colonial de Navegação, 1943:4).

A resposta a essa demanda nacional urgente veio com a publicação, em 10 de agosto de 1945, do Despacho 100 do Ministério da Marinha, sob o comando do Almirante Américo Thomaz, constituindo-se no Plano Geral de Renovação da Frota Mercante Nacional. Segundo o Despacho, nos últimos cinco anos havia-se gasto 309.000.000\$00 com reparação e conservação dos "velhos navios" que formam a frota mercante portuguesa. O Despacho recomendava que não se deviam repetir os mesmos "erros passados" (renovação da frota por meio da aquisição de navios obsoletos) e que deveria ser levada a cabo uma política de substituição dos velhos, gastos, lentos e antieconômicos navios, que constituem mais de $80 \%$ da nossa frota, por navios novos, de maior velocidade, econômicos e com uma tonelagem total que permita fazer face, em exploração normal, a não menos de 60\% das nossas necessidades globais de transporte (Ministério da Marinha, 1958:8).

Nas metas do Despacho 100 foram contempladas seis companhias de navegação: CCN, CNN, EIN, CNCA, SG e Sociedade de Transporte Carvoeiro Ltda. Ao todo, previa-se financiar a aquisição de 68 novos navios, totalizando 374.000 t. Era o maior plano de renovação da frota portuguesa até o momento. A CCN seria contemplada com o financiamento de 19 embarcações, com um total de 119.000 t. O Plano sofreu algumas alterações até o final de 1945, por exemplo, a obrigatoriedade de que 26 navios fossem construídos em estaleiros portugueses (Despacho 140, de 07/11/1945). Sem prazos definidos para atingir as metas estabelecidas no Plano, o fato é que a CCN, com recursos do FRMM, adquiriu 15 navios novos, totalizando 113.462 t. O primeiro navio a ser entregue foi o Benguela 2, em 1946, com 5.094 t; e o último foi o Uige, em 1954, com $10.001 \mathrm{t}$.

Quadro 3. Empréstimos obtidos pela CCN junto ao FRMM (1947-1972). Fonte: Relatórios e Contas da Companhia Colonial de Navegação, 1948-1973.

\begin{tabular}{|c|c|}
\hline Ano & Empréstimos (em Escudo) \\
\hline 1947 & $300.000 .000 \$ 000$ \\
\hline 1949 & $25.000 .000 \$ 000$ \\
\hline 1950 & $15.200 .000 \$ 000$ \\
\hline 1951 & $39.800 .000 \$ 000$ \\
\hline 1952 & $12.500 .000 \$ 00$ \\
\hline 1953 & $99.000 .000 \$ 00$ \\
\hline 1954 & $50.000 .000 \$ 00$ \\
\hline 1964 & $69.500 .000 \$ 00$ \\
\hline 1968 & $50.000 .000 \$ 00$ \\
\hline 1969 & $50.000 .000 \$ 00$ \\
\hline 1972 & $142.000 .000 \$ 00$ \\
\hline Total & $853.500 .000 \$ 00$ \\
\hline & \\
\hline
\end{tabular}


Em 1947, foi aberto um crédito de $300.000 .000 \$ 00$ junto ao FRMM para a CCN executar as metas previstas no Despacho 100. Até o ano de 1954, esse crédito foi sendo robustecido com mais recurso até atingir a cifra de 541.5000.000\$00 (Quadro 3). Na renovação promovida pelos planos de fomento foram obtidos mais empréstimos entre 1964 e 1972, no valor total de $311.500 .000 \$ 00$. As amortizações começaram somente em 1952 e se estendeu até o ano de 1974, conforme podemos observar no Quadro 4. Em 1974, a dívida com o Fundo era de 390.970.000\$00.

Quadro 4. Amortizações da CCN realizadas junto ao FRMM (1952-1972). Fonte: Relatórios e Contas da Companhia Colonial de Navegação, 1953-1973.

\begin{tabular}{|c|c|}
\hline Ano & Amortizações (em Escudo) \\
\hline 1952 & $10.000 .000 \$ 00$ \\
\hline 1953 & $12.500 .000 \$ 00$ \\
\hline 1954 & 18.500.000\$00 \\
\hline 1955 & $18.500 .000 \$ 00$ \\
\hline 1956 & $23.190 .000 \$ 00$ \\
\hline 1957 & $24.315 .000 \$ 00$ \\
\hline 1958 & $27.075 .000 \$ 00$ \\
\hline 1959 & $27.075 .000 \$ 00$ \\
\hline 1960 & $27.075 .000 \$ 00$ \\
\hline 1961 & $27.075 .000 \$ 00$ \\
\hline 1962 & $27.075 .000 \$ 00$ \\
\hline 1963 & $27.075 .000 \$ 00$ \\
\hline 1964 & $8.400 .000 \$ 00$ \\
\hline 1968 & $27.850 .000 \$ 00$ \\
\hline 1969 & $41.950 .000 \$ 00$ \\
\hline 1970 & $41.950 .000 \$ 00$ \\
\hline 1971 & $41.950 .000 \$ 00$ \\
\hline 1972 & $28.475 .000 \$ 00$ \\
\hline Total & $462.530 .000 \$ 00$ \\
\hline
\end{tabular}

Paralelamente aos créditos obtidos junto ao Fundo, a CCN também recorreu ao Fundo de Fomento Nacional (entre 1952 e 1958) e a seu sucessor, o Banco de Fomento Nacional (pós-1958). Em 1952, a CCN recebeu um aporte de 199.500.000\$00 do FFN, acrescido de mais $90.100 .000 \$ 00$ em 1958. Junto ao BFN, foram obtidos novos recursos financeiros em 1959 (40.100.000\$00), 1960 (40.100.000\$00), $1969(75.000 .000 \$ 00)$ e 1972 (34.000.000\$00). As duas instituições de créditos liberaram para a companhia, entre 1952 e 1972, o montante de 480.000.000\$00 (Quadro 5). 
Quadro 5. Saldos e recursos obtidos junto ao FFN e BFN (1952-1972). Fonte: Relatórios e Contas da Companhia Colonial de Navegação, 1953-1973.

\begin{tabular}{|c|c|c|}
\hline Ano & Fundo do Fomento Nacional & Banco de Fomento Nacional (em Escudo) \\
\hline 1952 & $199.500 .000 \$ 00$ & \\
\hline 1953 & $187.180 .237 \$ 00$ & \\
\hline 1954 & $171.148 .231 \$ 00$ & \\
\hline 1955 & $148.231 .293 \$ 90$ & \\
\hline 1956 & $135.331 .293 \$ 90$ & \\
\hline 1957 & $125.431 .293 \$ 90$ & \\
\hline 1958 & $215.531 .293 \$ 90$ & \\
\hline 1959 & & $255.631 .293 \$ 90$ \\
\hline 1960 & & $295.731 .293 \$ 90$ \\
\hline 1961 & & $281.294 .344 \$ 90$ \\
\hline 1962 & & $264.401 .850 \$ 20$ \\
\hline 1963 & & $247.221 .035 \$ 20$ \\
\hline 1964 & & $228.701 .596 \$ 20$ \\
\hline 1965 & & $208.752 .624 \$ 50$ \\
\hline 1966 & & $188.369 .015 \$ 90$ \\
\hline 1967 & & $176.804 .177 \$ 50$ \\
\hline 1968 & & $146.221 .553 \$ 80$ \\
\hline 1969 & & $221.197 .183 \$ 80$ \\
\hline 1970 & & $202.866 .004 \$ 50$ \\
\hline 1971 & & $189.908 .098 \$ 70$ \\
\hline 1972 & & $223.888 .676 \$ 60$ \\
\hline
\end{tabular}

Novas encomendas ocorreram no âmbito do II Plano de Fomento (1959-1964), que também previa dar continuidade à renovação permanente da frota. Para a CCN, foi prevista a compra de três novas embarcações, somando com 38.507 t. Dois navios foram construídos no Estaleiro Viana do Castelo, o Lobito 2, de 5.981 t, e o Porto de 9.220 t. O terceiro, o Infante Dom Henrique, o maior navio da companhia, com 23.306 $\mathrm{t}$, foi encomendado a um estaleiro belga, com capacidade para 318 tripulantes e 1.012 passageiros, e entrou em operação em 1961.

Por fim, a última renovação ocorreu dentro do III Plano de Fomento (1968-1973), quando foram encomendados três novos navios, somando ao todo $35.401 \mathrm{t}$. Desses, apenas um foi construído no território nacional, o Malenge (12.203 t), no Estaleiro de Viana; os outros dois, Bailundo 2 (11.586 t) e Bernadino Correa (11.612 t) - o último navio incorporado à frota - foram adquiridos no exterior.

Em resumo, tivemos seis momentos de ampliação e renovação da frota:

» Aquisição inicial com os navios Ganda e Guiné: 2 navios e 7.170 t

» Aquisições da TME, entre 1924 e 1926: 7 navios e 26.268 t

" Primeira renovação obsoleta, entre 1928 e 1931: 9 navios e 39.913 t

" Segunda renovação obsoleta, durante Segunda Guerra: 6 navios e 26.270 t

》 Renovação do Despacho 100, entre 1946 e 1954: 15 navios e 113.462 t

" Renovação dos planos de fomento

》 II Plano de Fomento, entre 1959 e 1968: 3 navios e 38.507 t

» III Plano de Fomento, entre 1969 e 1972: 3 navios e 35.401 t 
Na Figura 1 podemos acompanhar a evolução anual da frota da CCN e o volume total de TAB (Toneladas de Arqueação Bruta). Com relação à TAB percebe-se uma trajetória de crescimento entre 1922 e 1932, seguido de uma estabilidade, para retomar com mais intensidade pós-1945, quando foi posto em marchar a política de renovação da frota. Excluindo dois momentos de crescimento e queda brusca (ocasionado pela venda e compra de navios), o período seguinte, 1946 a 1959, seguiu um percurso de crescimento robusto. Após a renovação da frota a empresa ficou por quase uma década de fazer novas encomendas, o que explica os resultados dos anos seguintes até 1967. O mesmo movimento pode ser observado no total de embarcações, que acompanha a mesma trajetória do TAB, porém acrescido de uma queda no início da década de 1950, quando chegaram novas e maiores embarcações, passando de 18 navios em 1954

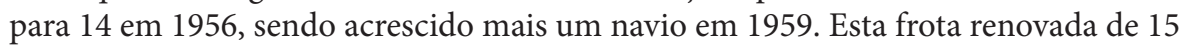
navios manteve-se por 12 anos, quando coincide com o período de crise e instabilidade comercial e financeira da CCN. A partir de 1968, chegaram os novos navios advindos do III Plano de Fomento.

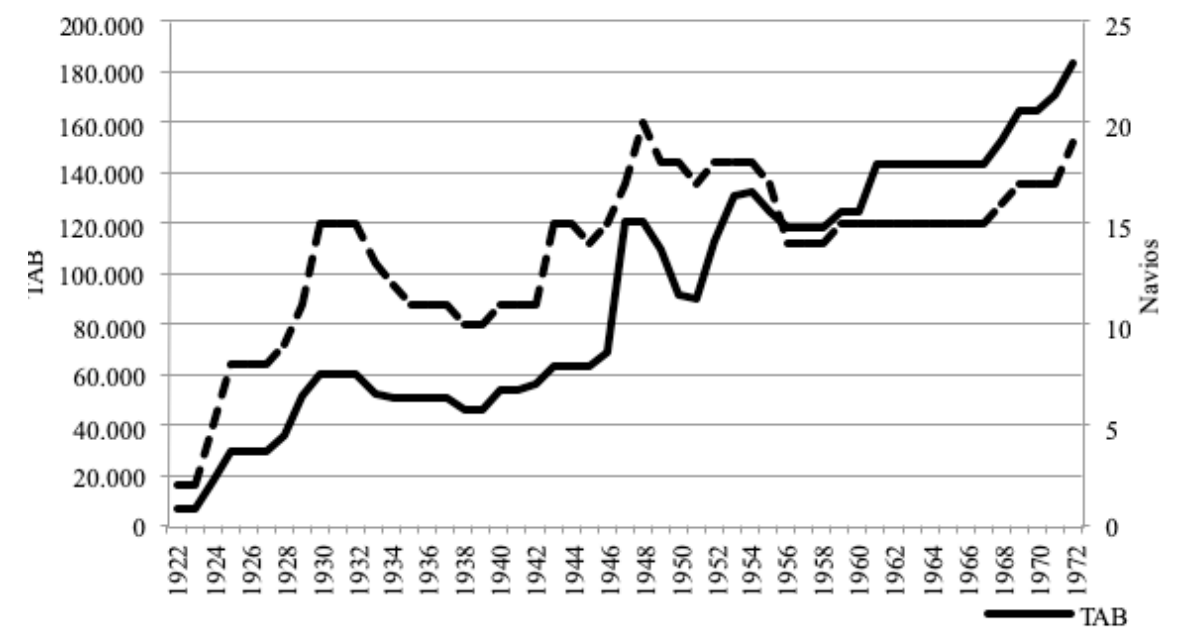

Figura 1. Trajetória da frota da CCN (1922-1972). Fonte: Relatórios e Contas da Companhia Colonial de Navegação, 1936-1973.

\section{Abertura, manutenção e encerramento de linhas}

A CCN foi criada com o objetivo inicial de atender o comércio colonial. Seus dois primeiros navios, o Ganda e o Guiné, faziam a carreira Portugal, Guiné, São Tomé a Angola, com escala em Cabo Verde. Em 1926, foi aberta a linha com portos do norte da Europa, que veio a ser encerrada em maio de 1934. Em 1929, estabeleceu-se a linha direta entre Portugal e Guiné, com escalas em Funchal e Cabo Verde. No ano seguinte, completando um dos principais objetivos da companhia, foi definida a linha até Moçambique, com escalas em Funchal, São Tomé, Angola e Cabo da Boa Esperança. A presença da $\mathrm{CCN}$ em Moçambique permitiu que fossem realizados serviços de cabotagem na própria colônia, ligando os principais portos moçambicanos (Lourenço Marques e Beira) (Companhia Colonial de Navegação, 1936).

Em 1938, as linhas africanas estavam assim definidas:

» Lisboa - Madeira - São Tomé - Ponta Negra (República do Congo) - Angola Cidade do Cabo (África do Sul) - Moçambique

》 Lisboa - Cabo Verde - São Tomé e Príncipe - Angola

» Lisboa - Madeira - Cabo Verde - Dakar (Senegal) - Guiné (Companhia Colonial de Navegação, 1939). 
Em 1940, foram criadas as carreiras de carga e passageiros para o Rio de Janeiro, com escala em Funchal, São Vicente, Santos e Nova York (Companhia Colonial de Navegação, 1941). Essas duas novas carreiras, somando à africana, faziam do Atlântico a ampla rota de navegação da companhia com possibilidades de conquistar novos portos. Desta forma, exigia ampliação e constante renovação da frota. Houve algumas viagens esporádicas para estudar a possibilidade de estabelecer uma linha fixa- como a passagem por México e Cuba em 1941; e pelo Marrocos no ano seguinte -, porém isso não se concretizou. Durante o período da Segunda Guerra, houve um arrefecimento das rotas marítimas para todas as companhias, uma vez que o fantasma dos bombardeamentos de submarinos rondava o Atlântico.

Após o fim dos conflitos e a volta à normalidade no Atlântico, a Colonial intensificou suas rotas com os EUA (Estados Unidos da América) e o Brasil. Até 1952, África, Brasil e EUA foram as três principais linhas mantidas pela CCN (Quadro 7). Com a entrada em operação da nova frota adquirida com base no Despacho 100, a Colonial buscou diversificar suas rotas. A linha para o Brasil foi estendida até Buenos Aires, com escala em Montevidéu. No dia 14 de agosto de 1953, o navio Serpa Pinto estabeleceu a rota entre Portugal e Venezuela (Porto de La Guaira, próximo a Caracas), com passagem por Curaçao e Havana. A linha ficou denominada de América Central, que em algumas viagens também fazia escala em Kingston, na Jamaica. Em ambas as linhas, América do Sul e América Central, havia uma escala em Vigo, na Espanha. Cabe assinalar que desse porto partiram numerosos emigrantes espanhóis, especialmente desde Galícia e das regiões empobrecidas do norte de Castilla e Astúrias.

Em função dos acordos estabelecidos com os EUA no âmbito do Plano Marshall, o comércio marítimo entre os dois países passou a ser realizado por armadores norteamericanos, o que levou a uma queda acentuada nos fluxos da Colonial. Em 1953, foi extinta a linha com os EUA e a empresa concentrou seus esforços em três frentes: África (colônias), América Central (Venezuela) e América do Sul (Brasil), além da cabotagem em Moçambique.

A empresa iniciou os anos 1960 com uma frota renovada, porém com reversão nas linhas. Em 1963, foi desativada a linha para Brasil, Uruguai e Argentina, o que representou, além de uma perda simbólica para a empresa, quedas acentuadas nos rendimentos. Segundo o relatório da CCN, o abandono da linha estava relacionado a ajustes cambiais no Brasil que geraram acúmulos de perdas e obrigaram a companhia a encerrar suas atividades na América do Sul. Para compensar essa perda e manter toda a frota na ativa, a Colonial tentou estabelecer uma nova rota entre Angola e portos do norte da Europa, porém tornou-se inviável e foi desativada em 1963. Soma-se a este cenário desfavorável à CCN, o início da Guerra Colonial, em 1961.

No final da década de 1960, foram mantidas apenas as linhas com as colônias e com a Venezuela. No entanto, esta segunda rota vinha acumulando constantes prejuízos ao longo dos anos 1960. O resultado desse cenário negativo foram perdas financeiras e prejuízos. Em 1971, novamente buscou-se restabelecer a rota entre norte da Europa e Angola, porém foi uma tentativa em vão e tardia, pois o inevitável estava por vir.

\section{Movimento comercial: carga, passageiros e viagens}

Para analisar os resultados do movimento de carga, passageiros e viagens, necessariamente temos que relacioná-los com a evolução e a renovação da frota e a abertura e o encerramento de linhas. A ampliação da frota disponibiliza mais navios para realizar viagens e a abertura de novas linhas demanda mais navios. Navios novos com maiores tonelagens elevam a produtividade e possibilitam diversificar rotas e conquistar novos mercados. Porém, nem sempre esta relação é tão direta assim. Na trajetória da CCN, 
podemos observar que esta fórmula cartesiana pode ser aplicada em determinados momentos, mas em outros, variáveis externas e internas de caráter incontroláveis conduziram a resultados inesperados.

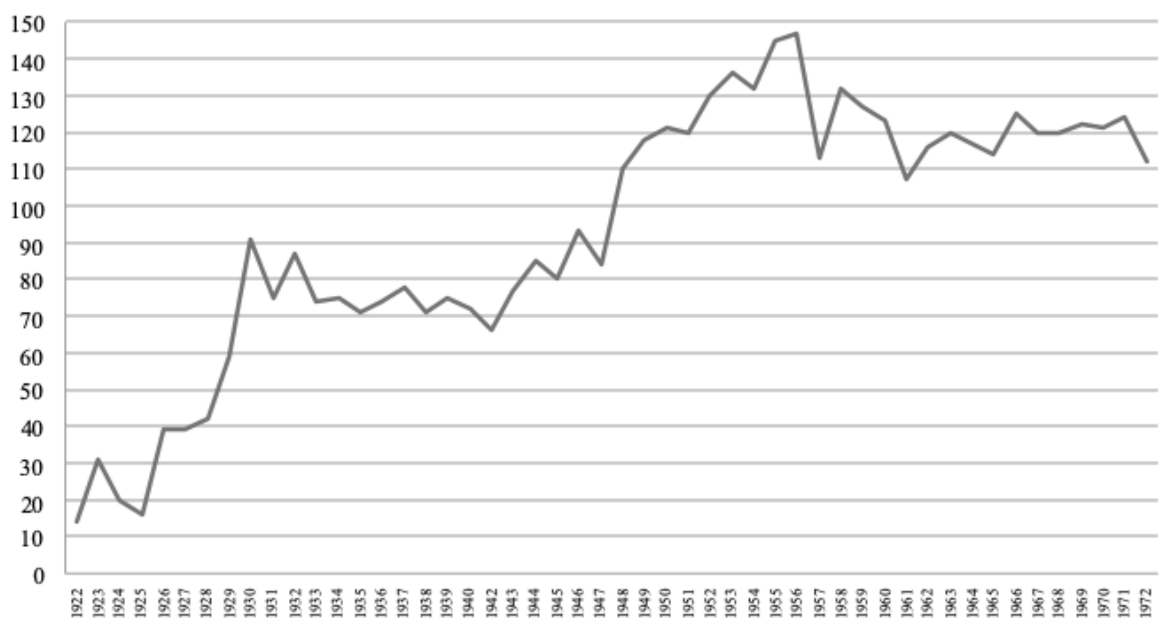

Figura 2. Viagens realizadas pela frota da CCN (1922-1972). Fonte: Relatórios e Contas da Companhia Colonial de Navegação, vários anos.

As aquisições da TME e as duas renovações obsoletas (1928-1931 e 1940-1943) elevaram o número de viagens, resultando no aumento de carga e passageiros transportados. Houve um crescimento constante das viagens até 1940, mas em seguida houve um arrefecimento durante a Segunda Guerra. Com a retomada da normalidade no Atlântico, a CCN expandiu suas linhas e viagens, mas no início da década de 1950 e durante os anos de 1960 até sua fusão, em 1974, tivemos momentos de queda no número de viagens realizadas, seguidos de estabilidade abaixo da plena capacidade de operação da frota, que havia sido renovada no âmbito do Despacho 100 (Figura 2). O mesmo movimento pode ser acompanhado no número de milhas percorridas, cujo crescimento desde os anos de 1922 sofreu um breve interregno durante a Segunda Guerra e retornou com força na década seguinte, mas a partir do início dos anos 1950 começou um ciclo de queda e instabilidade (Figura 3).

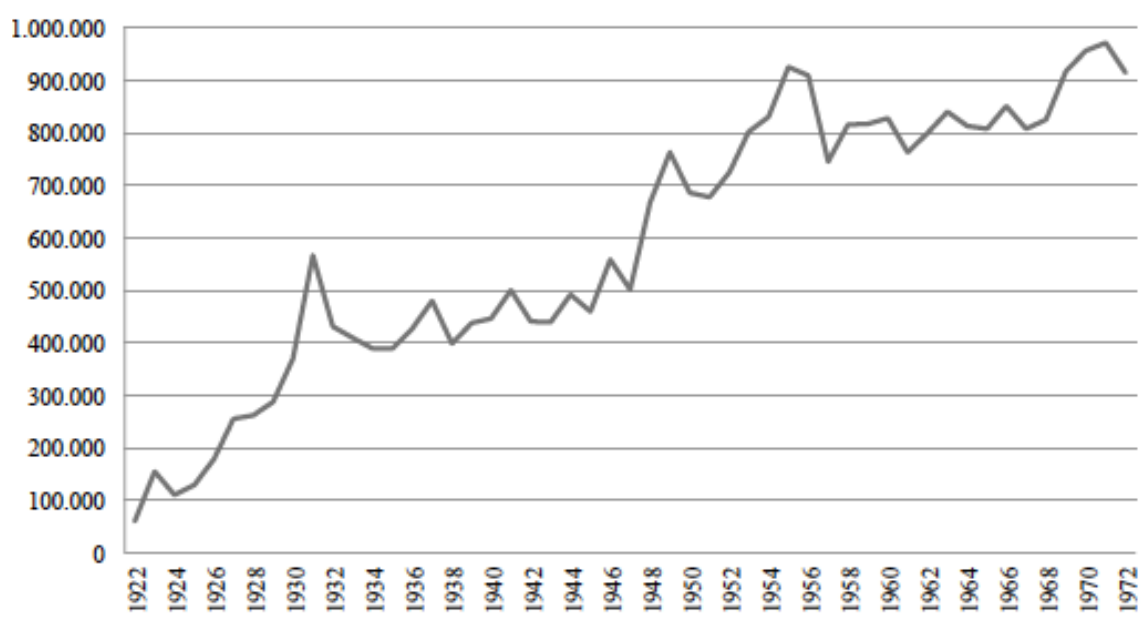

Figura 3. Milhas percorridas pela frota da CCN (1922-1972). Fonte: Relatórios e Contas da Companhia 
Colonial de Navegação, vários anos.

Esse padrão das viagens e milhas percorridas irá se repetir no volume de carga e passageiros transportados. Com relação ao volume de passageiros, houve um lento e contínuo crescimento até o final da Segunda Guerra, para em seguida assistirmos a um crescimento exponencial, entre 1948 e 1958. Os anos seguintes, até a fusão da companhia, foram de quedas pontuais e estabilidade abaixo da capacidade operacional da frota. Esse crescimento do pós-guerra está relacionando com o fluxo migratório de portugueses para a América e a queda tem uma relação direta com o desenvolvimento do transporte aéreo, sobretudo com a ampliação da Transportes Aéreos Portugueses (TAP), fundada em 1945 (Figura 4).

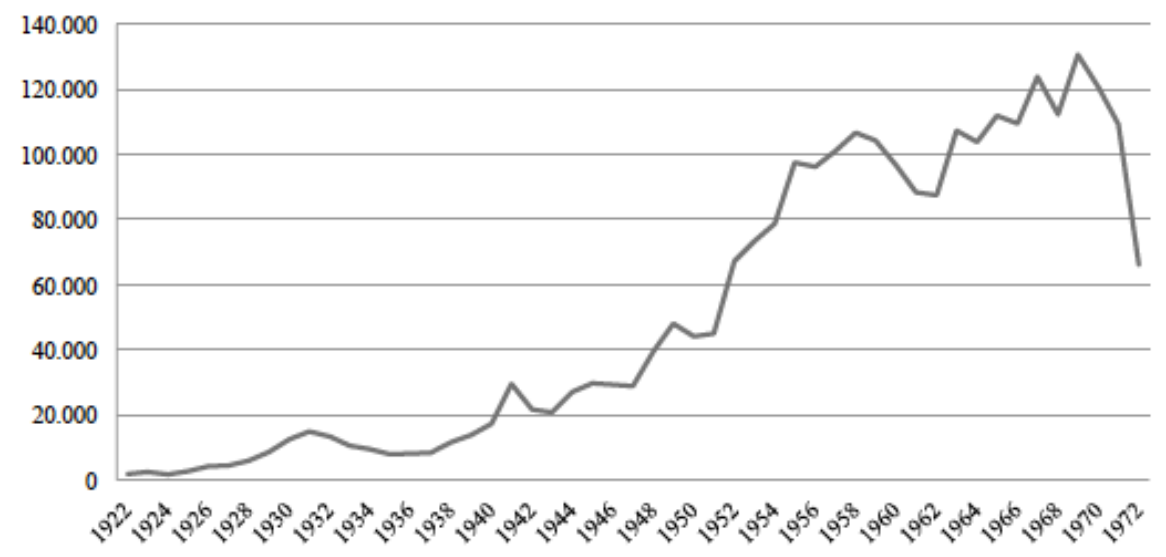

Figura 4. Movimento de passageiros da CCN (1922-1972). Fonte: Relatórios e Contas da Companhia Colonial de Navegação, vários anos.

O movimento de cargas seguiu crescendo até o início dos anos 1950. As demandas econômicas e os resultados imediatos do protecionismo pressionavam a CCN a ampliar sua frota para atender um mercado colonial em expansão que prometia retornos favoráveis ad infinitum. Ledo engano! Contraditoriamente, após a renovação da frota com embarcações novas advindas do Despacho 100, a tendência de crescimento no volume de carga transportada começou a se reverter. Entre 1953 e 1967, temos uma queda considerável, seguida de uma lenta recuperação estável, que colocava em questão se era realmente necessária a ampla renovação da frota, pois a mesma já estava operando com capacidade ociosa. No final da década de 1960, houve um breve surto de crescimento que parecia justificar as novas aquisições dentro dos Planos de Fomento, no entanto, este movimento parecer estar mais relacionado com as demandas da Guerra Colonial do que com a conquista de novos mercados. Os dois anos seguintes, $1971 \mathrm{e}$ 1972, foram de queda abrupta no volume de carga transportada, voltando à situação de 1967 (Figura 5). 


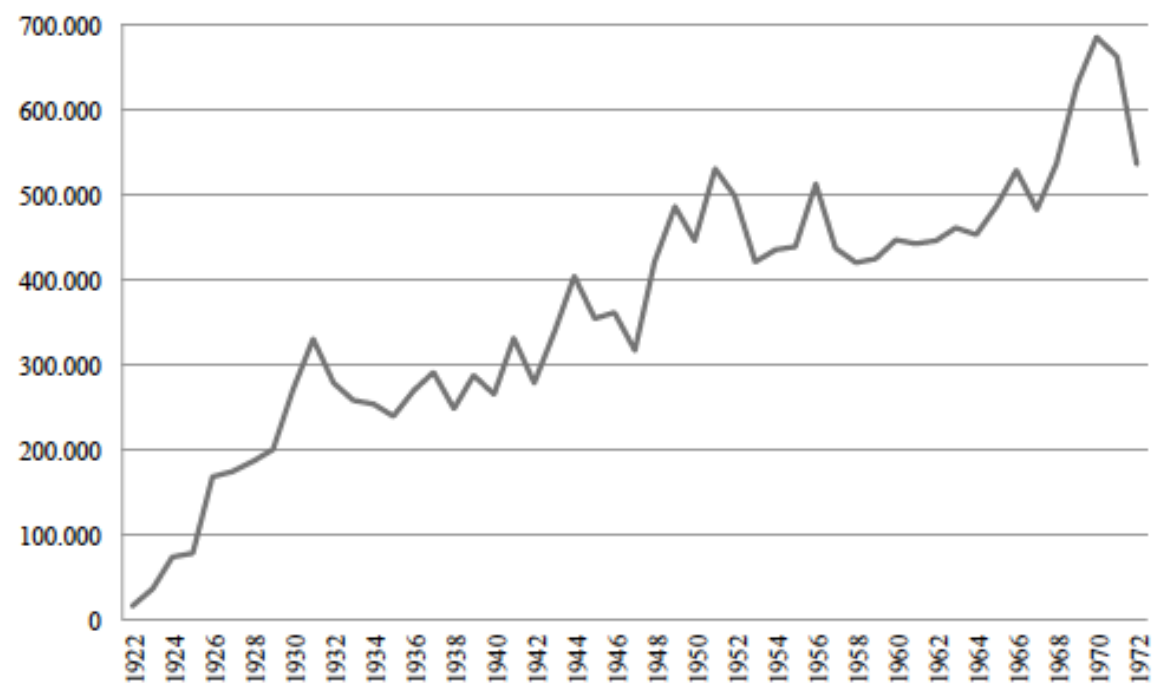

Figura 5. Volume total de carga transporta pela frota da CCN (1922-1972) (em t). Fonte: Relatórios e Contas da Companhia Colonial de Navegação, vários anos

A complexidade do problema da marinha mercante portuguesa não estava relacionada a duas deficiências (concorrência externa e obsolescência da frota) com duas possíveis soluções (proteção e renovação da frota). As prisões do tempo, do espaço e das liberdades individuais estão fora do controle dos agentes econômicos, os quais tomam decisões em um ambiente de incertezas históricas.

\section{Movimento financeiro: resultados e saldos}

Ampliar e renovar a frota deveria resultar em melhoras significativas nos resultados financeiros da CCN, mas, a exemplo da movimentação de cargas e passageiros, as finanças não seguiram a mesma tendência. Para a análise que faremos a seguir, temos disponíveis apenas os dados do balanço da empresa, de 1931 a 1971, sendo que entre 1952 e 1969 temos os saldos e os resultados financeiros, faltando a série das receitas e despesas. No entanto, é possível termos um bom panorama da situação financeira da Colonial.

Os primeiros anos da companhia foram de investimentos sem retorno imediato, uma vez que a empresa nasceu com um capital de 4.500.000\$00 e fez aquisições da TME, entre 1924 e 1926, no valor de 12.000.000\$00, pagas com empréstimos realizados junto ao Ministério das Colônias. Mesmo com novos aportes de capitais em 1924 e 1926, somente em 1936 os resultados financeiros começaram a ser positivos, uma vez que logo após as aquisições da TME, foi dado início a outro lote de compras, entre 1928 e 1931, quando foram incorporadas 9 embarcações à frota.

A partir de 1936, a CCN começou a estabilizar suas finanças, com geração de resultados (Lucros e Perdas) positivos, apesar dos saldos (Receita - Despesa) já apontarem como favoráveis desde 1931. Com relação aos saldos (preços constantes 1972), o crescimento é constante até 1936, quando segue em um aumento exponencial até 1941. A Segunda Guerra reverteu a tendência ascendente dos saldos e, a partir de 1944, inaugurou uma trajetória de ciclos curtos de aproximadamente de seis anos de expansão-queda-recuperação. Entre expansão e queda, 1944 a 1954, a média positiva dos saldos foi de 113.486.526\$86. A partir de 1955 até 1972, esta média anual sobe para 131.882.861\$76, mantendo os ciclos curtos. O último dado disponível é de 1972, 
que registrou um saldo negativo de $697.375 \$ 18$. Embora aparentemente pequeno o que assustava era a velocidade do crescimento das despesas (Quadro 6).

O resultado de Lucros e Perdas inicia a década de 1930 apresentando valores negativos que provavelmente estavam relacionados aos investimentos iniciais de composição (1924-1926) e renovação (1928-1931) da frota e aos juros pagos à Caixa Nacional de Crédito. Após o crescimento exponencial pós-1939, houve uma queda abrupta nos resultados, porém eles se mantiveram positivos. A sequência de ciclos curtos de expansão-queda-recuperação acompanha o movimento dos saldos, porém com uma tendência preocupante de queda da média. Entre 1961 e 1967, os resultados positivos se estabilizaram na média de $15.086 .109 \$ 08$. O curto crescimento entre 1968 e 1971, não foi capaz de evitar a falência da companhia, que, em 1972, apresentou um pífio resultado positivo de 1.419.897\$64 (Quadro 6).

Além do Decreto 13.101, de 29 de fevereiro de 1927, que abriu um crédito de 15.800.000\$00 para a CCN pagar as dívidas com a TME e saldar outros débitos, em 1931, por meio do Decreto 20.267 de 02 de setembro de 1931, o governo da Ditadura Militar autorizou a Caixa Nacional de Crédito, por intermédio do Banco de Fomento Colonial, a adquirir obrigações na ordem de $50.000 .000 \$ 00$ emitidas pelas empresas de Bernardino Alves Correias. Os valores seriam assim distribuídos: 25.000.000\$00 para a Companhia Geral de Angola; $20.000 .000 \$ 00$ para a Sociedade Agrícola do Cassequel; e 5.000.000\$00 para a Companhia Colonial de Navegação. Era o Estado corporativo financiando a manutenção e expansão do opressor complexo agráriomercantil colonial.

Entre 1927 e 1931, por meio de dois decretos, foram disponibilizados $20.800 .000 \$ 00$ à CCN, mesmo assim a empresa continuou a apresentar resultados negativos até 1935. Entre 1928 e 1935, a empresa pagou 7.026.685\$27 de juros em função dos empréstimos contraídos junto à Caixa Nacional de Crédito no âmbito dos dois decretos (Companhia Colonial de Navegação, 1936). A partir do início da década de 1950, tanto os saldos como os resultados, tornaram-se instáveis, ora apresentando leve tendência de crescimento, ora revertendo o movimento (Quadro 6). Esse movimento combina com a instabilidade e a crise no volume total de carga e passageiros transportados no mesmo período, repetindo a contradição: instabilidade financeira em um momento de renovação da frota. 
Quadro 6. Movimento financeiro da CCN (1931-1972). Fonte: Relatórios e Contas da Companhia Colonial de Navegação, 1936-1973.

\begin{tabular}{|c|c|c|c|c|}
\hline \multirow[t]{2}{*}{ Ano } & \multicolumn{3}{|c|}{ Resultado da Exploração (em Escudo) } & \multirow{2}{*}{$\begin{array}{l}\text { Resultado (Lucro } \\
\text { e perdas) (em } \\
\text { Escudo) }\end{array}$} \\
\hline & Receita & Despesa & Saldo & \\
\hline 1931 & $59.435 .098 \$ 76$ & $58.508 .257 \$ 93$ & $926.840 \$ 83$ & $(7.572 .540 \$ 89)$ \\
\hline 1932 & $54.844 .037 \$ 20$ & $47.658 .474 \$ 34$ & $7.185 .562 \$ 86$ & $(13.222 .968 \$ 11)$ \\
\hline 1933 & $54.947 .209 \$ 54$ & $43.925 .352 \$ 28$ & $11.021 .857 \$ 26$ & $(12.826 .525 \$ 06)$ \\
\hline 1934 & $51.469 .715 \$ 15$ & $40.284 .391 \$ 39$ & $11.185 .323 \$ 76$ & $(10.879 .635 \$ 48)$ \\
\hline 1935 & $46.826 .390 \$ 61$ & $37.743 .087 \$ 24$ & $9.083 .303 \$ 37$ & $(6.968 .800 \$ 03)$ \\
\hline 1937 & $68.282 .464 \$ 41$ & $53.789 .200 \$ 41$ & $14.493 .264 \$ 00$ & $9.689 .939 \$ 88$ \\
\hline 1938 & $59.536 .710 \$ 69$ & $46.989 .862 \$ 21$ & $12.546 .848 \$ 48$ & $193.347 \$ 25$ \\
\hline 1939 & $70.010 .417 \$ 59$ & $36.077 .967 \$ 07$ & $33.932 .450 \$ 52$ & $5.216 .226 \$ 91$ \\
\hline 1940 & $98.731 .601 \$ 41$ & $76.691 .423 \$ 08$ & $22.040 .178 \$ 33$ & $7.610 .610 \$ 07$ \\
\hline 1941 & $178.784 .623 \$ 65$ & $111.072 .204 \$ 98$ & $67.712 .418 \$ 67$ & $27.673 .388 \$ 76$ \\
\hline 1942 & $196.469 .243 \$ 64$ & $129.276 .086 \$ 49$ & $67.193 .157 \$ 15$ & $42.174 .057 \$ 75$ \\
\hline 1943 & $186.505 .000 \$ 00$ & $152.004 .000 \$ 00$ & $34.501 .000 \$ 00$ & $20.125 .277 \$ 06$ \\
\hline 1944 & $298.702 .644 \$ 12$ & $246.606 .451 \$ 19$ & $52.096 .192 \$ 93$ & $37.454 .193 \$ 73$ \\
\hline 1945 & $313.225 .961 \$ 89$ & $249.178 .869 \$ 36$ & $64.047 .092 \$ 53$ & $45.368 .708 \$ 82$ \\
\hline 1946 & $321.173 .772 \$ 37$ & $249.986 .452 \$ 36$ & $71.187 .320 \$ 01$ & $56.748 .378 \$ 56$ \\
\hline 1947 & $279.449 .128 \$ 56$ & $200.627 .363 \$ 96$ & $78.821 .764 \$ 60$ & $50.300 .551 \$ 40$ \\
\hline 1948 & $299.171 .000 \$ 00$ & $246.081 .000 \$ 00$ & $53.090 .000 \$ 00$ & $21.321 .078 \$ 20$ \\
\hline 1949 & $365.740 .000 \$ 00$ & $302.999 .000 \$ 00$ & $62.741 .000 \$ 00$ & $31.214 .066 \$ 02$ \\
\hline 1950 & $329.420 .000 \$ 00$ & $259.171 .000 \$ 00$ & $70.249 .000 \$ 00$ & $37.011 .177 \$ 86$ \\
\hline 1951 & $373.144 .000 \$ 00$ & $292.084 .000 \$ 00$ & $81.060 .000 \$ 00$ & $43.887 .228 \$ 89$ \\
\hline 1952 & & & $68.102 .224 \$ 73$ & $27.757 .678 \$ 77$ \\
\hline 1953 & & & $56.275 .609 \$ 08$ & $11.174 .584 \$ 82$ \\
\hline 1954 & & & $78.510 .902 \$ 62$ & $19.531 .917 \$ 50$ \\
\hline 1955 & & & 86.579.613\$04 & $22.761 .849 \$ 86$ \\
\hline 1956 & & & $90.177 .108 \$ 52$ & $25.286 .301 \$ 37$ \\
\hline 1957 & & & $102.526 .923 \$ 31$ & $33.665 .385 \$ 61$ \\
\hline 1958 & & & $97.050 .502 \$ 20$ & $29.268 .283 \$ 48$ \\
\hline 1959 & & & $97.757 .933 \$ 39$ & $23.588 .569 \$ 25$ \\
\hline 1960 & & & $90.963 .655 \$ 07$ & $20.756 .632 \$ 32$ \\
\hline 1961 & & & $90.922 .135 \$ 21$ & $14.753 .152 \$ 35$ \\
\hline 1962 & & & $119.661 .968 \$ 35$ & $14.196 .975 \$ 09$ \\
\hline 1963 & & & $114.889 .052 \$ 21$ & $15.723 .815 \$ 17$ \\
\hline 1964 & & & $108.392 .433 \$ 42$ & $12.863 .535 \$ 38$ \\
\hline 1965 & & & $106.968 .709 \$ 50$ & $15.918 .062 \$ 74$ \\
\hline 1966 & & & $97.850 .930 \$ 06$ & $16.266 .030 \$ 17$ \\
\hline 1967 & & & $96.803 .573 \$ 11$ & $15.881 .192 \$ 67$ \\
\hline 1968 & & & $103.637 .383 \$ 35$ & $27.197 .852 \$ 55$ \\
\hline 1969 & & & $120.347 .216 \$ 62$ & $36.727 .853 \$ 23$ \\
\hline 1970 & $958.222 .495 \$ 80$ & $827.315 .900 \$ 04$ & $130.906 .559 \$ 76$ & $35.754 .965 \$ 10$ \\
\hline 1971 & $947.716 .525 \$ 03$ & $818.657 .836 \$ 92$ & $129.058 .688 \$ 11$ & $22.022 .522 \$ 46$ \\
\hline 1972 & $1.008 .597 .506 \$ 82$ & $1.008 .597 .506 \$ 82$ & $(697.375 \$ 18)$ & $1.419 .897 \$ 64$ \\
\hline
\end{tabular}

A fusão da CCN com a EIN em 04 de fevereiro de 1974, coordenada pela Empresa de Tráfego e Estiva, foi realizada com o intuito de evitar a insolvência da Colonial, uma vez que os eventos políticos no país já anunciavam sua falência. Há de se ressaltar também que, em 11 de dezembro de 1972, ocorreu a fusão por incorporação da Companhia Nacional de Carregadores Açoriana pela EIN. 


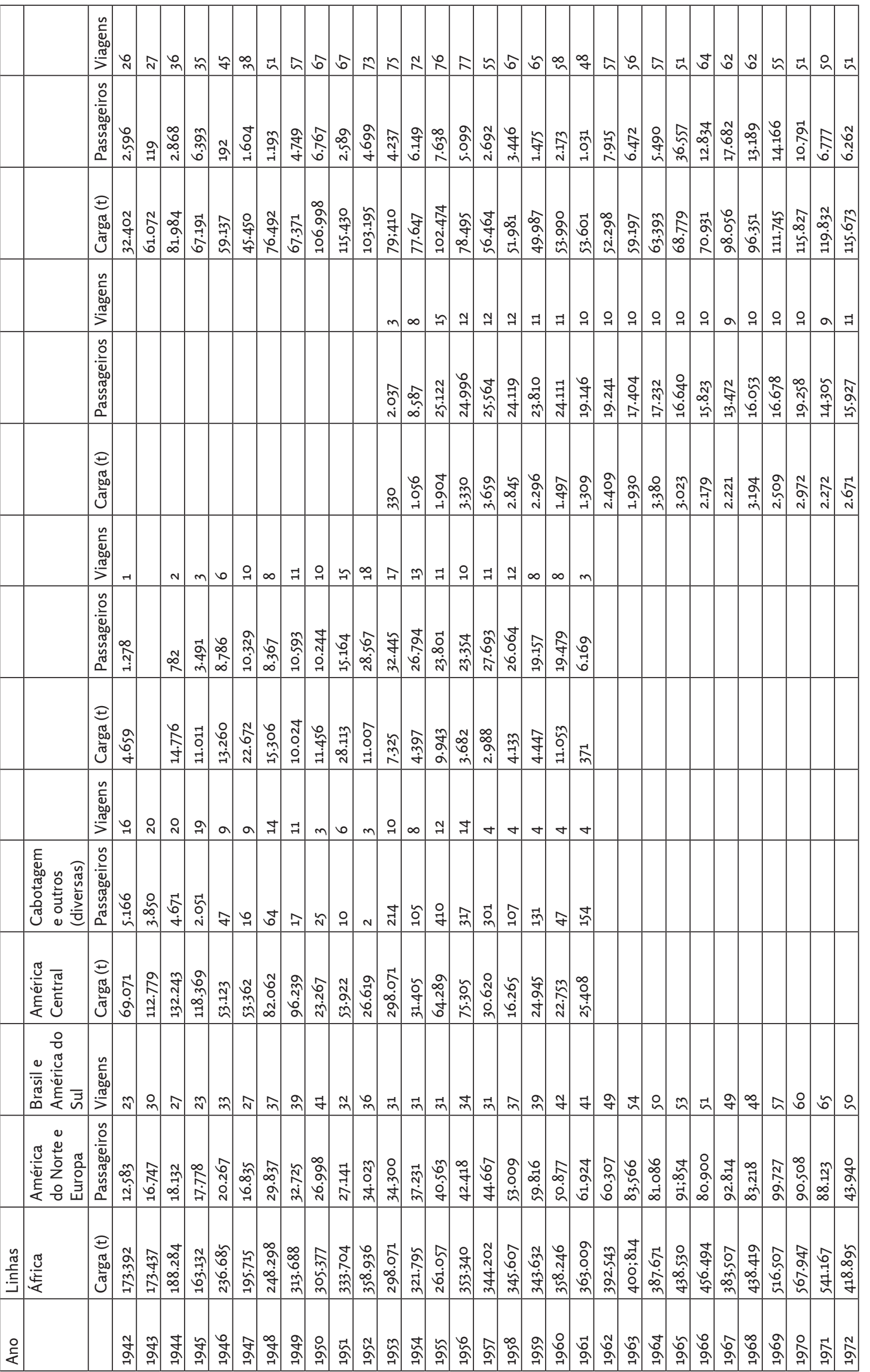




\section{Composição e alterações do capital}

De acordo com o Estatuto aprovado em 31 de julho de 1922, a CCN, com sede em Lobito, Angola, nasceu para atender a navegação entre as colônias portuguesas e outros mercados. Possuía um capital de 4:500.000\$00, divido em 45.000 ações de $100 \$ 00$ cada (Portugal, 1922). A reforma estatutária de 22 de março de 1923 mudou a sede da companhia para Lisboa, porém na prática continuou em Lobito (Portugal, 1923). Somente em 01 de maio de 1945, em outra alteração estatutária, é que a sede efetivamente passou para Lisboa (Portugal, 1945).

Em função das aquisições nos leilões da TME, em 24 de fevereiro de 1924, o capital foi elevado para $9.000 .000 \$ 00$, representado por 90.000 ações a $100 \$ 00$ cada (Portugal, 1924). Como o volume total das compras foi de $12.000 .000 \$ 00$ ( $£ 48.288$ ), superando o capital social, o conselho da administração da CCN solicitou um novo aporte de capital a seus acionistas. Em 16 de abril de 1926, ocorreu mais uma mudança estatutária e o capital social aumentou mais 6.000.000\$00, passando para 15.000.000\$00 (Portugal, 1926).

Em 1939, em 04 de maio, o capital foi reduzido para 7.750.000\$00 (Portugal, 1939). Essa mudança abrupta ocorreu justamente em um momento em que a empresa se preparava para fazer uma nova rodada de renovação da frota, entre 1940 e 1943, quando foram adquiridos seis navios.

As duas últimas alterações do capital social ocorreram durante a execução do Despacho 100. Em 03 de julho de 1951, houve uma alteração considerável, passando para $75.000 .000 \$ 00$, divididos em 125.000 ações de $600 \$ 00$ cada uma (Portugal, 1951). Segundo o relatório da CCN de 1951:

As 77.500 ações antigas foram valorizadas em Esc. $500 \$ \$ 00$ cada uma, sem desembolso, e as 47.500 ações restantes foram oferecidas a subscrição pública, realizada no decurso do mês de janeiro deste ano e que foi totalmente preenchida (Companhia Colonial de Navegação, 1952:7).

Por fim, em 13 de outubro de 1953, a que tudo indica, diante de dificuldades financeiras que começavam a emergir, ocorreu o último aumento de capital, passando para $150.000 .000 \$ 00$ por meio da emissão de 120.000 ações no valor de $600 \$ 00$ cada uma (Portugal, 1953). Este novo aumento significou uma estatização parcial da companhia, pois a emissão foi "integralmente tomada pelo Fundo de Fomento Nacional, Caixa de Previdência, Banco Nacional Ultramarino e Banco de Angola" (Companhia Colonial de Navegação, 1954:8). Esse arranjo financeiro era o modelo empresarial do Estado corporativo.

Quadro 8. Composição do capital social da CCN. Fonte: Relatórios e Contas da Companhia Colonial de Navegação, 1936-1954.

\begin{tabular}{|c|c|}
\hline Ano & Capital Social (em Escudo) \\
\hline 1922 & $4.500 .000,00$ \\
\hline 1924 & $9.000 .000,00$ \\
\hline 1926 & $15.000 .000,00$ \\
\hline 1939 & $7.750 .000,00$ \\
\hline 1951 & $75.000 .000,00$ \\
\hline 1953 & $150.000 .000,00$ \\
\hline
\end{tabular}




\section{Troca de favores entre o público e o privado}

Dentro dos fundamentos do Estado corporativo português, a troca de favores entre agentes privados e setores da esfera estatal era muito comum. Se, por um lado, o Estado concedia subsídios, liberava recursos para compra de embarcações e garantia o mercado por meio do protecionismo alfandegário para os armadores locais, por outro, a elite da burocracia fascista esperava ser bem atendida quando fossem solicitados os serviços marítimos das companhias nacionais.

Entre os diversos diplomas editados, destacamos os decretos de 1927 e 1931, que disponibilizam ao todo $20.800 .000 \$ 00$ à CCN. Também ressaltamos os créditos liberados pelo Banco Ultramarino de Angola, pelo Banco de Fomento Colonial e pelo Banco de Fomento Nacional, a inclusão da companhia no II e no III Plano de Fomento e os benefícios alfandegários garantidos pela Junta Nacional da Marinha Mercante.

Em compensação, entre os favores retribuídos ao Estado português, o mais recorrente era a cessão de embarcações para o transporte de comitivas do executivo, ou até mesmo da comunidade eclesiástica, em viagens para as colônias ou em eventos específicos na Europa. Durante as guerras coloniais, também houve o afretamento de navios da CCN para o transporte de pessoas e mantimentos.

Em junho de 1937, no âmbito da Exposição Histórica da Ocupação, realizada em Lisboa no Pavilhão do Parque Eduardo VII, a CCN promoveu, a pedido do Ministério das Colônias, o "Primeiro Cruzeiro de Férias dos Estudantes das Colônias à Metrópole", transportando alunos dos liceus de Angola e Moçambique a bordo do paquete Colonial (Companhia Colonial de Navegação, 1938).

No ano seguinte, em 1938, foi realizada a viagem presidencial à Moçambique, com a presença do presidente Oscar Carmona e dos ministros das Colônias (Francisco José Vieira Machado) e da Marinha (Manuel Ortins Torres de Bettencourt). A comitiva viajou ao bordo do paquete Colonial entre os dias 17 de junho e 13 de setembro (Companhia Colonial de Navegação, 1939).

Em 15 de junho de 1944, ainda em plena Segunda Guerra, o Cardeal Patriarca de Lisboa, Manuel Gonçalves Cerejeira, partiu de Lisboa a bordo do luxuoso Serpa Pinto em direção a Loureço Marques (atual Maputo). Na capital moçambicana, o Cardeal inaugurou a Catedral da Nossa Senhora da Conceição (Companhia Colonial de Navegação, 1945). Em 1945, após a normalização do tráfego no Atlântico, o Ministro das Colônias, Marcelo Caetano, fez um recorrido nas colônias africanas utilizando a rota do vapor Mouzinho (Companhia Colonial de Navegação, 1946).

Quando da canonização do Beato João de Brito em 22 de junho de 1947, a comitiva eclesial de Lisboa e Lourenço Marques viajou até o porto italiano de Civitavecchia, a bordo do Mouzinho. De lá, a comitiva se dirigiu até o Vaticano para o ato solene da canonização. O regresso teve partida no porto de Gênova (Companhia Colonial de Navegação, 1948)

Como toda marinha mercante é considerada reserva da marinha de guerra, era comum o Ministério da Marinha afretar navios dos armadores portugueses para auxiliar na manutenção do opressor colonialismo. Em setembro de 1937, o Ministério da Marinha requisitou o vapor Mouzinho para auxiliar na guerra colonial em Macau, retornando em janeiro de 1938. Assim definiu a CCN: 
Prestou a nossa Companhia ao país mais um importante serviço. A requisição inesperada do paquete Mouzinho causou alguma perturbação nos serviços que, aliás, rapidamente se normalizaram (Companhia Colonial de Navegação, 1938:5).

O paquete Colonial ficou sob guarda da Marinha de julho de 1949 a março de 1950, sendo utilizando na rota entre Luanda e Macau (Companhia Colonial de Navegação, 1950). Substituindo Oscar Carmona, após 25 anos na presidência da República, o novo mandatário, Francisco Higinio Craveiro Lopes, repetiu a tradição de seu antecessor e fez, em agosto de 1955, um périplo pelas colônias portuguesas na África:

Aproveitando a feliz circustância da realização, em agosto do ano corrente, da viagem da Sua Excelência o Senhor Presidente da República a Moçambique, a Companhia, correspondendo, nomeadamente, ao interesse superiormente manifestado, projetou efetuar naquela data um cruzeiro périplo aos portos de África, o qual, servindo por um lado para dar contributo, embora modesto, ao brilho das manifestações que se preparam naquela província em honra ao Supremo Magistrado da Nação, proporcionando a muitos metropolitanos a alegria de se associarem a tão grato acontecimento, contribuirá, por outro, uma ocasião magnífica para o português do continente conhecer, em condições excepcionalmente favoráveis, as grandiosas parcelas do nosso Império (Companhia Colonial de Navegação, 1956: 8).

Américo Rodriguez Thomaz também realizará suas viagens em 1962 para as ilhas da Madeira e Açores; e, em 1963, em plena Guerra Colonial, para São Tomé, Angola e Moçambique.

Era comum a Diretoria da CCN saudar, em seus relatórios anuais, eventos e personalidades, reafirmando seu apoio ao Estado Novo. Em 1958, Américo Thomaz foi felicitado por sua eleiçãoà presidência da República, após polêmica e acirrada disputa com o General Humberto Delgado. Quando do ousado "assalto ao Santa Maria" da Companhia Nacional de Navegação, em 22 de janeiro de 1961, a CCN se solidarizou com sua concorrente e fez duras críticas à Organização das Nações Unidas (ONU). Américo Thomaz novamente é elogiado por sua reeleição em 1965. E, por fim, foram registradas condolências à enfermidade de Salazar em 1968 e a sua morte em 1970.

Também havia os tradicionais agradecimentos aos bancos que lhe concediam créditos. No Relatório de 1938, há um agradecimento à Caixa Nacional de Crédito e a Direção da Marinha Mercante "pelo desvelado interesse que a navegação nacional lhes continua merecendo" (Companhia Colonial de Navegação, 1939, p. 9). O Banco Nacional Ultramarino era constantemente citado nos agradecimentos pelos créditos cedidos: "Ao Banco Nacional Ultramarino renovamos os protestos da nossa gratidão pelo valioso concurso financeiro dispensado à nossa Companhia" (Companhia Colonial de Navegação, 1949:15). Os agradecimentos foram se estendendo ao longo de todos os relatórios.Abaixo, trecho do ano de 1956:

Cumpre-lhe ainda renovar os seus agradecimentos aos Exmo dirigentes da Junta Nacional da Marinha Mercante, da Junta de Emigração, do Fundo de Renovação da Marinha Mercante, do Fundo de Fomento Nacional, dos bancos com quem manteve especiais relações de interesse mútuo, designadamente o Banco Nacional Ultramarino, o Banco de Angola e o Crédit Franco-Portugais (Companhia Colonial de Navegação, 1956:11).

Nos anos 1960, os agradecimentos estenderam-se ao Banco de Fomento Nacional, ao Banco Português do Atlântico e ao Banqueiros Augustine, Reis \& Cia, além de demais órgãos nacionais vinculados ao setor naval que formulavam políticas de fomento à marinha mercante. 


\section{Considerações finais}

A relação entre os "problemas da marinha mercante" apontados pelos especialistas do setor naval português (obsolescência da frota, concorrência desleal e falta de proteção) e suas possíveis soluções (protecionismo e crédito) tem uma estreita relação com a trajetória da CCN. A Companhia Colonial de Navegação se beneficiou do protecionismo e do comércio marítimo com as colônias africanas - além da cabotagem em Moçambique -, recebeu subsídios para saldar débitos contraídos para a renovação da frota (aquisições da TME), teve acesso a crédito junto a bancos públicos e privados e fez parte dos planos de renovação da frota do Despacho 100 e dos II e III Plano de Fomento. Porém, esse conjunto de políticas e benefícios promovido e concedido pelo Estado Novo não impediu que a empresa entrasse em uma espiral deficitária e fosse fundida em março de 1974 com a Empresa Insulana de Navegação para formar a Companhia Portuguesa de Transportes Marítimos.

A CCN chegou ao início dos anos 1960 com uma frota renovada e com capacidade para atender boa parte do comércio colonial português, além de outras rotas em direção à América do Sul (Brasil) e Central (Venezuela). Portanto, de acordo com os diagnósticos feitos pelos especialistas que se debruçavam sobre o "problema da marinha mercante", esperava-se um novo período de prosperidade para a Companhia. Contraditoriamente, foi neste momento, na década de 1960, que a Colonial começou a apresentar resultados comerciais e financeiros abaixo do esperado.

Variáveis externas, fora do controle dos gestores da CCN passaram a incidir diretamente nos destinos da empresa. A Guerra Colonial e o enfraquecimento do Estado Novo ofuscaram o horizonte dos rendimentos futuros da companhia, revelando que era uma empresa que dependia de um regime imperial e autoritário. O fim do colonialismo e a luta pela democracia em Portugal anunciavam o fim da CCN. 


\section{Q Bibliografia}

" Companhia Colonial de Navegação (1927). Subsídios para o estudo das ligações marítimas com as colônias portuguesas. Lisboa: Tipografia do Comércio.

»Companhia Colonial de Navegação (1936-1973). Relatório e contas da Companhia Colonial de Navegação. Lisboa: CCN, (série completa).

»Companhia Colonial De Navegação (1947). Vinte e cinco anos ao serviço da Nação: fundação, vida e tarefa da Companhia Colonial de Navegação. Lisboa: Sociedade Industrial de Tipografia.

» Ferreira, António Lopes (1937). Marinha mercante nacional: subsídios para o estudo da sua reorganização. Lisboa: Tipografia Americana.

» Ferreira, V. T. (1937). Marinha mercante: problema nacional. Revista de Marinha. Lisboa, 1 (4).

» Junta Nacional Da Marinha Mercante (1972). O 50ํaniversário da Companhia Colonial de Navegação. Boletim da Junta Nacional da Marinha Mercante. Lisboa: Núcleo de Planejamento e Estudo, 81.

»Leone, J. C. de O. (1903). Pela marinha mercante. Lisboa: Papelaria La Bécarre.

»Leone, J. C. de O. (1910). O problema da marinha mercante. Lisboa: Imprensa Africana.

» Leitão, J. A. C. (1930). Capitais estrangeiros na marinha mercante nacional. Lisboa: Tipografia Cristóvão A. Rodrigues.

»Lopes, J. M. (2002). Caminho de Ferro do Amboim: breve ensaio histórico. Luanda: Editora do Autor.

» Mattos, A. P. de (1900). A marinha de comércio. Porto: Magalhães \& Muniz Editores.

» Ministério da Marinha (1966). A marinha nos últimos 40 anos. Lisboa: Ministério da Marinha.

» Ministério da Marinha (1958). Renovações e expansão da frota mercante nacional: despachos do Ministério da Marinha. Lisboa: Ministério da Marinha.

» Medeiros, J. H. G. da C. de (1934). O problema da marinha mercante nacional. Lisboa: Jornal do Comércio e das Colônias.

» Medeiros, J. H. G. da C. de (1939). O problema da marinha mercante. Lisboa: Oficina Gráfica.

» Moreira, A. P. da S. (1939). O problema da marinha mercante nacional: navegação para as colônias - subsídios para o seu estudo e solução. Lisboa: Sociedade Tipográfica Ltda.

»Sousa, A. B. de (1919). O problema da marinha mercante. Lisboa: Tipografia de J. F. Pinheiro.

\section{Fuentes}

»Portugal. Companhia Colonial de Navegação. In: Diário do Governo. Lisboa: 
Imprensa Nacional, n. 178, série III, 03/agosto/1922.

»Portugal. Companhia Colonial de Navegação. In: Diário do Governo. Lisboa: Imprensa Nacional, n. 69, 24/março/1923.

»Portugal. Companhia Colonial de Navegação. In: Diário do Governo. Lisboa: Imprensa Nacional, n. 32, série III, o9/fevereiro/1924.

»Portugal. Companhia Colonial de Navegação. In: Diário do Governo. Lisboa: Imprensa Nacional, n. 97, série III, 26/abril/1926.

"Portugal. Companhia Colonial de Navegação. In: Diário do Governo. Lisboa: Imprensa Nacional, n. 121, série III, 26/maio/1939.

"Portugal. Companhia Colonial de Navegação. In: Diário do Governo. Lisboa: Imprensa Nacional, n. 125, série III, 31/maio/1945.

»Portugal. Companhia Colonial de Navegação. In: Diário do Governo. Lisboa: Imprensa Nacional, n. 160, série III, 13/julho/1951.

"Portugal. Companhia Colonial de Navegação. In: Diário do Governo. Lisboa: Imprensa Nacional, n. 241, série III, 15/outubro/1953.

"Portugal. Decreto 7.822 de 22 de novembro de 1921. In: Diário do Governo. Lisboa: Imprensa Nacional, n. 153, série I, p. 994. Disponível em <https://dre. $\mathrm{pt} / \mathrm{home}>$. Acesso em 10 de março de 2018.

"Portugal. Decreto 13.101 de 29 de fevereiro de 1927. In: Diário do Governo. Lisboa: Imprensa Nacional, n. 24, série I, p. 18o. Disponível em <https://dre.pt/ home>. Acesso em 10 de março de 2018.

"Portugal. Decreto 15.360 de 03 de abril de 1928. In: Diário do Governo. Lisboa: Imprensa Nacional, n. 85, série I, p. 918. Disponível em <https://dre.pt/home>. Acesso em 10 de março de 2018.

»Portugal. Decreto n 16.499 de 19 de fevereiro de 1929. In: Diário do Governo. Lisboa: Imprensa Nacional, n. 40, série I, p. 532. Disponível em <https://dre.pt/ home>. Acesso em 10 de março de 2018.

»Portugal. Decreto 20.267 de 02 de setembro de 1931. In: Diário do Governo. Lisboa: Imprensa Nacional, n. 202, série I, p. 1987. Disponível em <https://dre. pt/home>. Acesso em 10 de março de 2018.

"Portugal. Decreto 20.321 de 18 de setembro de 1931. In: Diário do Governo. Lisboa: Imprensa Nacional, n. 2016, série I, p. 2.062. Disponível em <https:// dre.pt/home>. Acesso em 10 de março de 2018.

»Portugal. Decreto-Lei 29.962 de 09 de outubro de 1939. In: Diário do Governo. Lisboa: Imprensa Nacional, n. 236, série I, p. 1.065. Disponível em <https://dre. pt/home >. Acesso em 10 de março de 2018.

"Portugal. Decreto-Lei 35.876 de 24 de setembro de 1946. In: Diário do Governo. Lisboa: Imprensa Nacional, n. 2017, série I, p. 88o.Disponível em <https://dre. pt/home >. Acesso em 10 de março de 2018.

\section{Alcides Goularti Filho / alcides@unesc.net}

Doutorado em Ciência Econômica pela Universidade Estadual de Campinas (2001) na área de História Econômica. Pós-doutorado pela Faculdade de Economia da Universidade de Coimbra. Professor da Universidade do Extremo Sul Catarinense (UNESC) do Curso de Economia e do Programa de Pós-graduação em Desenvolvimento 
Socioeconômico (PPGDS). Presidente da Associação Brasileira de Pesquisadores em História Econômica (ABPHE) 2017-2019.

\section{António Rafael Amaro / aamaro@fe.uc.pt}

Atua na área de História Económica Contemporânea. Mestre e doutorado em História Contemporânea, com a tese (publicada) Economia e Desenvolvimento da Beira Alta do fim da Monarquia à II Guerra Mundial (1890-1945). É professor na Faculdade de Economia da Universidade de Coimbra, Grupo de História Económica. Tem cinco livros publicados e dezenas de artigos em revistas da especialidade. É Investigador integrado do Centro de Estudos Interdisciplinares do Século XX da Universidade de Coimbra (CEIS20), onde coordena o grupo de Investigação História e Memória.

\section{Álvaro Garrido / agarrido@fe.uc.pt}

É professor associado com agregação da Faculdade de Economia da Universidade de Coimbra, onde coordena o grupo de História Económica e Social. Investigador integrado do Centro de Estudos Interdisciplinares do Século XX (CEIS20). O seu trabalho incide na História Económica contemporânea e na história das instituições do Estado Novo português. Os temas do corporativismo, das pescas e da economia do mar e da economia social são centrais no seu projeto de investigação. Recentemente publicou: Cooperação e Solidariedade. Uma História da Economia Social (Tinta-da-China, 2016); Queremos uma Economia Nova! O Corporativismo Salazarista (Temas \& Debates/ Círculo de Leitores, 2016) e As Pescas em Portugal (Col. Ensaios da Fundação Francisco Manuel dos Santos, 2018). 